\title{
Front Matter: Volume 8691
}

, "Front Matter: Volume 8691," Proc. SPIE 8691, Nanosensors, Biosensors, and Info-Tech Sensors and Systems 2013, 869120 (30 April 2013); doi: $10.1117 / 12.2030022$

Event: SPIE Smart Structures and Materials + Nondestructive Evaluation and Health Monitoring, 2013, San Diego, California, United States 


\title{
Nanosensors, Biosensors, and Info-Tech Sensors and Systems 2013
}

\author{
Vijay K. Varadan \\ Editor \\ 10-14 March 2013 \\ San Diego, California, United States \\ Sponsored by \\ SPIE \\ Cosponsored by \\ American Society of Mechanical Engineers (United States) \\ Cooperating Organizations \\ Intelligent Materials Forum (Japan) \\ Jet Propulsion Laboratory (United States) \\ National Science Foundation (United States) \\ Published by \\ SPIE
}


The papers included in this volume were part of the technical conference cited on the cover and title page. Papers were selected and subject to review by the editors and conference program committee. Some conference presentations may not be available for publication. The papers published in these proceedings reflect the work and thoughts of the authors and are published herein as submitted. The publisher is not responsible for the validity of the information or for any outcomes resulting from reliance thereon.

Please use the following format to cite material from this book:

Author(s), "Title of Paper," in Nanosensors, Biosensors, and Info-Tech Sensors and Systems 2013, edited by Vijay K. Varadan, Proceedings of SPIE Vol. 8691 (SPIE, Bellingham, WA, 2013) Article CID Number.

ISSN: 0277-786X

ISBN: 9780819494740

Published by

SPIE

P.O. Box 10, Bellingham, Washington 98227-0010 USA

Telephone +1 3606763290 (Pacific Time) · Fax +1 3606471445

SPIE.org

Copyright (C) 2013, Society of Photo-Optical Instrumentation Engineers.

Copying of material in this book for internal or personal use, or for the internal or personal use of specific clients, beyond the fair use provisions granted by the U.S. Copyright Law is authorized by SPIE subject to payment of copying fees. The Transactional Reporting Service base fee for this volume is $\$ 18.00$ per article (or portion thereof), which should be paid directly to the Copyright Clearance Center (CCC), 222 Rosewood Drive, Danvers, MA 01923. Payment may also be made electronically through CCC Online at copyright.com. Other copying for republication, resale, advertising or promotion, or any form of systematic or multiple reproduction of any material in this book is prohibited except with permission in writing from the publisher. The CCC fee code is 0277-786X/13/\$18.00.

Printed in the United States of America.

Publication of record for individual papers is online in the SPIE Digital Library.

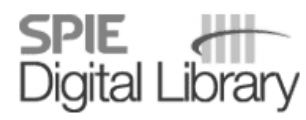

SPIEDigitallibrary.org

Paper Numbering: Proceedings of SPIE follow an e-First publication model, with papers published first online and then in print and on CD-ROM. Papers are published as they are submitted and meet publication criteria. A unique, consistent, permanent citation identifier (CID) number is assigned to each article at the time of the first publication. Utilization of CIDs allows articles to be fully citable as soon as they are published online, and connects the same identifier to all online, print, and electronic versions of the publication. SPIE uses a six-digit CID article numbering system in which:

- The first four digits correspond to the SPIE volume number.

- The last two digits indicate publication order within the volume using a Base 36 numbering

system

employing both numerals and letters. These two-number sets start with 00, 01, 02, 03, 04, 05, 06,

$07,08,09,0 A, O B \ldots 0 Z$, followed by 10-1Z, 20-2Z, etc.

The CID Number appears on each page of the manuscript. The complete citation is used on the first page, and an abbreviated version on subsequent pages. Numbers in the index correspond to the last two digits of the six-digit CID Number. 


\section{Contents}

ix Conference Committee

KEYNOTE SESSION

869101 Development of sensing techniques for weaponry health monitoring (Keynote Paper) [8691-1]

E. Edwards, P. B. Ruffin, E. A. Walker, C. L. Brantley, U.S. Army Research, Development and Engineering Command (United States)

869104 Moving technologies from the test tube to commercial products (Keynote Paper) [8691-37] R. G. Bryant, NASA Langley Research Ctr. (United States)

POINT-OF CARE HEALTH MONITORING

869106 Wireless health monitoring helmet for football players to diagnose concussion and track fatigue [8691-3]

S. Oh, P. Kumar, H. Kwon, P. Rai, M. Ramasamy, The Univ. of Arkansas (United States);

V. K. Varadan, The Univ. of Arkansas (United States) and Pennsylvania State Univ. (United States) and Global Institute of Nanotechnology in Engineering and Medicine Inc. (United States)

\section{NANOSENSORS AND SYSTEMS I}

869108 Smart real-time cardiac diagnostic sensor systems for football players and soldiers under intense physical training [8691-6]

P. S. Kumar, S. Oh, The Univ. of Arkansas (United States); H. Kwon, P. Rai, The Univ. of Arkansas (United States); V. K. Varadan, The Univ. of Arkansas (United States) and Pennsylvania State Univ. (United States) and Global Institute of Nanotechnology in Engineering and Medicine, Inc. (United States)

869109 Micromotion-induced dynamic effects from a neuron probe and brain tissue interface [8691-7] M. Polanco, Old Dominion Univ. (United States); H. Yoon, Norfolk State Univ. (United States); S. Bawab, Old Dominion Univ. (United States)

8691 OA Motion artifact removal algorithm by ICA for e-bra: a women ECG measurement system [8691-8]

H. Kwon, S. Oh, The Univ. of Arkansas (United States); V. K. Varadan, The Univ. of Arkansas (United States) and Pennsylvania State Univ. (United States) and Global Institute of Nanotechnology in Engineering and Medicine Inc. (United States) 


\section{SMART ELECTRONICS}

8691 OB Flexible paper transistor made with ZnO-cellulose hybrid nano-composite for electronic applications [8691-9]

H.-U. Ko, Inha Univ. (Korea, Republic of); G.-H. Kim, Chosun Univ. (Korea, Republic of) and Inha Univ. (Korea, Republic of); S.-Y. Yang, J. Kim, Inha Univ. (Korea, Republic of); J.-H. Kim, Chosun Univ. (Korea, Republic of) and Inha Univ. (Korea, Republic of)

8691 OE Fault detection in word-level nanolCs using vector Boolean derivatives [8691-12]

S. C. Lee, F. T. Aula, The Univ. of Oklahoma (United States)

8691 OF Logic design of word-level 3D, 2-dot QCA nanolCs [8691-13]

S. C. Lee, L. Hook IV, F. T. Aula, The Univ. of Oklahoma (United States)

\section{NANO - MICRO SYSTEMS II}

8691 ol Overcoming obstacles to creating complex MEMS platforms: parallels with the semiconductor and computer design industries (Invited Paper) [8691-16]

L. Shannon, Simon Fraser Univ. (Canada)

8691 OK Fabrication of nano-island structures and application to solar cells [8691-18]

I. Seok, J. Falls, S. Haran, Arkansas State Univ. (United States)

\section{NANO - MICRO SYSTEMS III}

8691 OM Bio-inspired design: nonlinear digital pixels for multiple-tier processes [8691-21]

O. Skorka, A. Mahmoodi, J. Li, D. Joseph, Univ. of Alberta (Canada)

8691 ON Polyimide neural probe for chronic sensing of neural activity and micro-positioning [8691-22]

C. S. Smith, D. W. Scott, M. H. Kim, Norfolk State Univ. (United States); L. D. Sanford, Eastern Virginia Medical School (United States); K. D. Song, H. Yoon, Norfolk State Univ. (United States)

869100 Development of magneto-impedance microsensors for the detection of deep-lying defects using eddy current testing [8691-23]

T. Peng, Lab. de Génie Électrique de Paris, CNRS, Univ. Paris Sud (France) and CNRS, Institut d'Électronique Fondamentale, Univ. Paris Sud (France); J. Moulin, CNRS, Institut d'Électronique Fondamentale, Univ. Paris Sud (France); Y. Le Bihan, F. Alves, Lab. de Génie Électrique de Paris, CNRS, Univ. Paris Sud (France)

FLEXIBLE NANO- AND MICROSYSTEMS

8691 OP Conformal printing of sensors on 3D and flexible surfaces using aerosol jet deposition [8691-24]

T. Blumenthal, V. Fratello, G. Nino, K. Ritala, QUEST Integrated, Inc. (United States) 
$86910 Q \quad$ Particle based conductive silver ink customized for ink jet printing on cellulose electro-active paper [8691-25]

M. A. H. Khondoker, S. C. Mun, J. Kim, Inha Univ. (Korea, Republic of)

8691 OR Development of thermoelectric inks for the fabrication of printable thermoelectric generators used in mobile wearable health monitoring systems [8691-26]

J. Lee, The Univ. of Arkansas (United States); H. J. Kim, National Institute of Aerospace (United States); L. Chen, The Univ. of Arkansas (United States); S. H. Choi, NASA Langley Research Ctr. (United States); G. N. Mathur, V. K. Varadan, The Univ. of Arkansas (United States)

8691 OS Synthesis and properties of cellulose functionalized -4, 4'-(propane-2, 2'-diyl) diphenol$\mathrm{SiO}_{2} / \mathrm{TiO}_{2}$ hybrid nanocomposites materials for high performance applications [8691-27] S. Ramesh, G.-H. Kim, Chosun Univ. (Korea, Republic of) and Inha Univ. (Korea, Republic of); H.-S. Kim, Dongguk Univ. (Korea, Republic of); J. Kim, Inha Univ. (Korea, Republic of); J.-H. Kim, Chosun Univ. (Korea, Republic of) and Inha Univ. (Korea, Republic of)

MICROWAVE, RF NANOMATERIALS

8691 OV 3D RF integration at VTT [8691-30]

T. Vähä-Heikkilä, VTT Technical Research Ctr. of Finland (Finland)

FABRICATION AND CHARACTERIZATION I

$86910 Z$ Electromagnetic characteristics of Polyaniline/SWCNT composites [8691-34]

B. Javvaji, D. Roy Mahapatra, S. Raha, Indian Institute of Science (India)

869110 Strain measurements on scattered, highly oriented CNTs [8691-35]

S. Geier, T. Mahrholz, J. Riemenschneider, P. Wierach, Deutsches Zentrum für Luft- und Raumfahrt e.V. (Germany); M. Sinapius, Technical Univ. of Braunschweig (Germany)

\section{FABRICATION AND CHARACTERIZATION II}

869113 Synthesis and electrochemical properties of spinel lithium manganese oxides for lithium ion batteries [8691-39]

G. Wang, Nanjing Forestry Univ. (China) and The Univ. of Arkansas (United States) and Shaoxing Univ. (China); L. Chen, G. N. Mathur, V. K. Varadan, The Univ. of Arkansas (United States)

869114 Electrical and electromechanical behaviors of ZnO-cellulose hybrid nanocomposites [8691-40]

S. Mun, L. Zhai, Inha Univ. (Korea, Republic of); B.-W. Kang, Inha Univ. (Korea, Republic of) and Samsung Electro-Mechanics (Korea, Republic of); J. Kim, Inha Univ. (Korea, Republic of) 
869115 Study of the electrochemical properties of magnetite, maghemite and hematite nanoparticles for their applications in lithium ion batteries [8691-41]

L. Chen, The Univ. of Arkansas (United States); G. Wang, Shaoxing Univ. (China); J. Xie, Agilent Technologies (United States); P. Rai, J. Lee, G. N. Mathur, V. K. Varadan, The Univ. of Arkansas (United States)

\section{FABRICATION AND CHARACTERIZATION III}

869117 Visualization of interior structures with nanoscale resolution using ultrasonic-atomic force microscopy [8691-43]

D. R. Kwak, S. H. Kim, I. Park, Seoul National Univ. of Science and Technology (Korea, Republic of); J. A. Todd, C. Miyasaka, Pennsylvania State Univ. (United States)

869118 Hybrid nanocomposites made with cellulose and $\mathrm{ZnO}$ nanoparticles and its biosensing application [8691-44]

S.-D. Jang, M. Maniruzzaman, G.-Y. Yun, J. Kim, Inha Univ. (Korea, Republic of)

8691 1A Fabrication of CZTS-based thin film solar cells using all-solution processing and pulsed light crystallization [8691-46]

C. Munn, S. Haran, I. Seok, Arkansas State Univ. (United States)

\section{METAMATERIALS AND OPTICAL NANOSTRUCTURES}

8691 1C Nanoscale imaging of mesh size distribution in gel engineering materials with visual scanning microscopic light scattering [8691-48]

Y. Watanabe, M. H. Kabir, J. Gong, H. Furukawa, Yamagata Univ. (Japan)

8691 1D Characterization of shape memory gels using scanning microscopic light scattering [8691-49]

M. H. Kabir, Y. Watanabe, J. Gong, H. Furukawa, Yamagata Univ. (Japan)

$8691 \mathrm{lE} \quad$ Modelling of the structure-property relationships in the a-quartz structures [8691-50] Y. Yao, Harbin Institute of Technology (China) and Univ. Of Bolton (United Kingdom); K. Alderson, A. Alderson, Univ. of Bolton (United Kingdom); J. Leng, Harbin Institute of Technology (China)

NANO - MICRO SYSTEMS

8691 1G A novel nano-scaled force sensor based on silicon photonic crystal [8691-52]

T. Li, L. Li, W. Song, G. Zhang, Y. Li, Harbin Institute of Technology (China)

\section{POSTER SESSION}

$8691 \mathrm{lH}$ Analysis of nano-indentation test for polycrystalline materials by modified strain gradient theory [8691-53]

B.-B. Jung, H.-C. Park, Pohang Univ. of Science and Technology (Korea, Republic of) 
8691 1J Hardware efficient seizure prediction algorithm [8691-55]

S. Consul, B. I. Morshed, R. Kozma, The Univ. of Memphis (United States)

$86911 \mathrm{~K}$ The model of random signals generated by optical particle counter and the instrument improvement [8691-56]

Z. Yan, B. Bian, Nanjing Univ. of Science and Technology (China); K. Yan, Nanjing Univ. of Science and Technology (China) and Xi'an Technological Univ. (China); C. Wang, Z. Li, Nanjing Univ. of Science and Technology (China)

Author Index 
Proc. of SPIE Vol. $8691869120-8$

Downloaded From: https://www.spiedigitallibrary.org/conference-proceedings-of-spie on 26 Apr 2023 Terms of Use: https://www.spiedigitallibrary.org/terms-of-use 


\section{Conference Committee}

Symposium Chairs

Norbert G. Meyendorf, Fraunhofer-Institut für Zerstörungsfreie Prüfverfahren (Germany) and University of Dayton (United States) Norman M. Wereley, University of Maryland, College Park

(United States)

Symposium Cochairs

Victor Giurgiutiu, University of South Carolina (United States)

Christopher S. Lynch, University of California, Los Angeles

(United States)

Conference Chair

Vijay K. Varadan, University of Arkansas (United States)

Conference Cochairs

Jaehwan Kim, Inha University (Korea, Republic of)

Kyo D. Song, Norfolk State University (United States)

Sang H. Choi, NASA Langley Research Center (United States)

Yongrae Roh, Kyungpook National University (Korea, Republic of)

Conference Program Committee

Christina Brantley, U.S. Army Aviation and Missile Command (United States)

Natalie Clark, NASA Langley Research Center (United States)

Kimiya Komurasaki, The University of Tokyo (Japan)

Ajit Khosla, Simon Fraser University (Canada)

Kunik Lee, Turner-Fairbank Highway Research Center (United States)

Uhn Lee M.D., Gachon University Gil Medical Center (Korea, Republic of)

Xinxin Li, Shanghai Institute of Microsystem and Information Technology (China)

Yanjian Liao, Chongaing University (China)

Samuel C. Lee, The University of Oklahoma (United States)

D. Roy Mahapatra, Indian Institute of Science (India)

Yeonjoon Park, National Institute of Aerospace (United States)

Parag Ganapathi Patil, University of Michigan Health System (United States)

II-Kwon Oh, KAIST (Korea, Republic of) 
Aswini K. Pradhan, Norfolk State University (United States)

Paul Ruffin, U.S. Army Aviation and Missile Command (United States)

Ashok Srivastava, Louisiana State University (United States)

Tauno Vaha-Heikkila, VTT Technical Research Center of Finland

(Finland)

W-C. Wang, University of Washington (United States)

Richard K. Watt, Brigham Young University (United States)

Hargsoon Yoon, Norfolk State University (United States)

T. C. Yih, California State University, Long Beach (United States)

Ming Zhou, Suzhou Institute of Nano-tech and Nano-bionics (China)

\section{Session Chairs}

Keynote Session

Vijay K. Varadan, University of Arkansas (United States)

Sang H. Choi, NASA Langley Research Center (United States)

Point-of Care Health Monitoring

Vijay K. Varadan, University of Arkansas (United States) and

Pennsylvania State University (United States)

Nanosensors and Systems I

Hargsoon Yoon, Norfolk State University (United States)

Smart Electronics

Prasyush Rai, University of Arkansas (United States)

Nano - Micro Systems I

Ajit Khosla, Simon Fraser University (Canada)

Nano - Micro Systems II

Christina L. Brantley, U.S. Army Research, Development and Engineering Command (United States)

Nano-Micro Systems III

Dileepan Joseph, University of Alberta (Canada)

Flexible Nano-and Microsystems

Christina L. Brantley, U.S. Army Research, Development and Engineering Command (United States)

Microwave, RF Nanomaterials

Lesley Shannon, Simon Fraser University (Canada)

Fabrication and Characterization I

Ajit Khosla, Simon Fraser University (Canada)

Fabrication and Characterization II 
Hyun-U Ko, Inha University (Korea, Republic of)

Fabrication and Characterization III

Shivan Haran, Arkansas State University (United States)

Metamaterials and Optical Nanostructures

Ajit Khosla, Simon Fraser University (Canada)

Nano-Micro Systems

Ajit Khosla, Simon Fraser University (Canada) 
Proc. of SPIE Vol. $8691869120-12$

Downloaded From: https://www.spiedigitallibrary.org/conference-proceedings-of-spie on 26 Apr 2023 Terms of Use: https://www.spiedigitallibrary.org/terms-of-use 